\title{
Teorias econômicas marxistas e a Grande Recessão
}

\author{
Marxist economic theories and the Great Recession
}

ALEX WILHANS ANTONIO PALLUDETO ROGERIO P. DE ANDRADE*

RESUMO: O presente artigo dedica-se ao exame de algumas das principais interpretações de inspiração marxista acerca da Grande Recessão que se apresentam publicadas sob a forma de livros. Do amplo conjunto de publicações sobre o tema, as seguintes obras foram analisadas: The Great Financial Crisis, de John Bellamy Foster e Fred Magdoff (2009); The Enigma of Capital, de David Harvey (2011), publicada originalmente em 2010; The Crisis of Neoliberalism, de Gérard Duménil e Dominique Lévy (2011); e The Failure of Capitalist Production, de Andrew Kliman (2012). Argumenta-se que o debate marxista em torno das causas últimas da Grande Recessão pode ser sistematizado a partir da seguinte clivagem: 1) de um lado, os autores que atribuem a turbulência à forma política/econômica/institucional específica assumida pelo sistema capitalista ao longo das últimas décadas; 2) de outro, aqueles que interpretam a crise recente como uma manifestação própria da dinâmica capitalista em geral - e não do modo particular que esta supostamente apresenta. Enquanto Foster e Magdoff (2009), Harvey (2011) e Duménil e Lévy (2011) compõem o primeiro grupo, Kliman (2012) pode ser visto como representante da segunda vertente.

PALAVRAS-CHAVE: teorias marxistas da crise; Grande Recessão; neoliberalismo; taxa de lucro.

ABSTRACT: This review paper examines some of the main Marxist-inspired interpretations of the Great Recession that were published in the form of books. From the broad set of publications on the subject, the following works were analyzed: The Great Financial Crisis, by John Bellamy Foster and Fred Magdoff (2009); The Enigma of Capital, by David Harvey (2011), originally published in 2010; The Crisis of Neoliberalism, by Gérard Duménil and Dominique Lévy (2011); and The Failure of Capitalist Production, by Andrew Kliman (2012). It is argued that the Marxist debate about the ultimate causes of the Great Recession can be systematized from the following cleavage: 1 ) on the one hand, the authors who

\footnotetext{
* Instituto de Economia da Universidade de Campinas (IE/Unicamp).E-mails: alex.wilhans@gmail.com e roger.andrade@uol.com.br. Submetido: 16/março/2015; Aprovado: 1/agosto/2016.
} 
attribute the turbulence to the specific political/economic/institutional form assumed by the capitalist system over the last decades; 2) on the other hand, those who interpret the recent crisis as a manifestation of capitalist dynamics in general - and not the particular form that it supposedly assumes. While Foster and Magdoff (2009), Harvey (2011) and Duménil and Lévy (2011) belong to the first group, Kliman (2012) is a representative of the second strand.

KEYWORDS: Marxist theories of crises; Great Recession; neoliberalism; rate of profit. JEL Classification: E11; G01.

\section{INTRODUÇÃO}

O objetivo deste artigo-resenha é apresentar algumas das principais interpretações marxistas sobre a "Grande Recessão" de 2007-2009 veiculadas sob a forma de livros: The Great Financial Crisis, de John Bellamy Foster e Fred Magdoff (2009); The Enigma of Capital, de David Harvey (2011), publicado originalmente em 2010; The Crisis of Neoliberalism, de Gérard Duménil e Dominique Lévy (2011); e The Failure of Capitalist Production, de Andrew Kliman (2012).

Inicialmente, três importantes considerações devem ser feitas. Em primeiro lugar, como o objetivo do artigo consiste em expor algumas das principais interpretações marxistas da crise recente (a última grande crise do capitalismo), as resenhas abaixo limitar-se-ão a apresentar apenas os argumentos estritamente necessários à compreensão dos determinantes da crise para cada autor (ou autores). Com efeito, embora a crise contemporânea seja o leimotiv, as obras aqui analisadas eventualmente abordam questões que, ainda que relacionadas à crise, não fazem parte do estudo sobre suas causas e, portanto, serão desconsideradas. Em outras palavras, buscaremos nos concentrar nas explicações da crise. Suas possíveis implicações geopolíticas, seus efeitos quanto aos rumos a serem seguidos pela política econômica dos países afetados, as estratégias que devem ser adotadas pela esquerda diante desse cenário etc. não serão contemplados.

Em segundo lugar, cabe destacar que uma vez que há um relativo consenso quanto às causas imediatas, isto é, ao estopim da crise recente, a atenção dos autores recai, sobretudo, sobre suas causas últimas, ou estruturais, para as quais, de fato, concentra-se o debate marxista contemporâneo. Dessa forma, na exposição dos argumentos das obras apresentadas abaixo pouco destaque será dado aos impactos imediatos da expansão e do colapso do mercado hipotecário norte-americano, considerado o principal elemento deflagrador da crise recente. Ainda que possam existir entre os autores importantes divergências em relação aos mecanismos específicos de propagação das turbulências nesse mercado para a economia como um todo, há pouca dúvida de que estes foram o mais importante gatilho da crise - fato evidenciado, ademais, no espaço relativamente reduzido que dedicam em suas obras a esse tema. O mesmo não ocorre, contudo, quanto ao que consideram como as causas estruturais da crise. Se é para essa questão, portanto, que os autores discutidos destinam seus maiores esforços para o entendimento da crise recente, é natural 
que um trabalho que pretenda apresentar suas obras e contrastar suas respectivas visões quanto às causas da crise, como é o caso deste, nela se atenha.

Por último, cabe ressaltar que não pretendemos avaliar a consistência teórica e empírica das obras aqui tomadas como representativas do debate marxista contemporâneo sobre a crise. Como já observado, procuraremos apenas apresentar as principais interpretações sobre o tema, sobretudo na tentativa de estimular discussões dessa natureza entre os economistas heterodoxos brasileiros que, com raras exceções ${ }^{1}$, parecem alheios ao fervoroso debate que se trava entre os marxistas no exterior.

Embora não exista na obra de Marx de forma bem articulada e sistematizada uma teoria geral da crise capitalista, este tema é objeto recorrente de análise na economia política marxista. Não é surpresa, portanto, que a última grande crise do capitalismo, conhecida como "Grande Recessão", seja área de estudos de uma ampla gama de teóricos marxistas contemporâneos.

Um aspecto central das teorias marxistas das crises capitalistas é que estas são o resultado da operação das contradições inerentes ao modo de produção capitalista. Elas não se originam de eventos que ocorrem fora do sistema econômico, de forma exógena, mas emergem em virtude do seu próprio desenvolvimento. A evolução temporal do modo de produção capitalista dá-se de maneira tal a gerar, ainda que sob distintas formas, inevitáveis contradições que, em algum momento do processo histórico, só se "resolvem" por meio de crises.

A indagação que então se coloca é: quais são essas contradições? A identificação daquela que se crê central na explicação da crise é um dos elementos que permitem separar as várias abordagens marxistas sobre o tema. Neste sentido, na literatura econômica marxista são tradicionalmente consideradas três vertentes mais gerais que procuram explicar a natureza das crises: a teoria do subconsumo (por ex., Rosa de Luxemburgo, Paul Sweezy), a das desproporções interdepartamentais (Rudolf Hilferding) e a baseada na lei da tendência à queda da taxa de lucro (Paul Mattick, David Yaffe) ${ }^{2}$.

Outro critério de avaliação das crises econômicas capitalistas usualmente empregado diz respeito a se suas causas são concebidas em termos determinísticos ou como potência. Ao examinar as teorias marxistas da crise ao longo da história, tomando como referência a lei de tendência à queda da taxa de lucro, Shaikh (1991) identificou duas perspectivas de análise:

possibility theories, based on the notion of law as the resultant of conflicting tendencies, in which general crises occur if and when there is a certain conjunction of historically determined factors; and necessity

\footnotetext{
${ }^{1}$ Alguns exemplos são os trabalhos de Gontijo e Oliveira (2009), Filgueiras (2010), Cipolla (2012) e Prado (2013).

2 Para uma apreciação crítica mais detalhada das várias teorias marxistas da crise desde Marx e Engels a partir dessa categorização, ver Clarke (1994, 2012).
} 
theories, based on the notion of law as the expression of an intrinsic dominant tendency that subordinates counter-vailing ones, in which the periodic occurrence of general crises is inevitable (though, of course, the specific form and timing is determined, within limits, by historical and institutional factors) (Shaikh, 1991, p. 161).

Este artigo-resenha, contudo, propõe um critério alternativo para a organização da literatura marxista acerca da crise recente, baseado em Palludeto (2013), que, ao contrário dos mencionados acima, parece típico do debate atual: ao invés de tentar classificar as várias correntes de acordo com o setor no qual identificam as causas últimas da crise recente - se na economia real ou nas finanças ${ }^{3}$ - parece promissor considerar, por um lado, aqueles autores que veem a crise contemporânea como uma manifestação de uma determinada fase do sistema capitalista e, por outro, aqueles que a creditam à dinâmica geral do capitalismo. Em outras palavras, a partir deste debate, é possível estabelecer a seguinte clivagem: 1) de um lado, os autores que atribuem a turbulência à forma política/econômica/institucional específica assumida pelo sistema capitalista ao longo das últimas décadas (ou neoliberalismo); 2) de outro, aqueles que interpretam a crise recente como uma manifestação própria da dinâmica capitalista em geral - e não do modo particular que esta supostamente apresenta. Dessa classificação inicial não se deve apreender, naturalmente, que as considerações de uma das abordagens sejam completamente ignoradas pelas da outra. Trata-se, isto sim, do peso atribuído por cada qual, seja à configuração hodierna do capitalismo, seja às relações mais elementares e gerais que governam sua dinâmica. Que a conformação econômica contemporânea - qualquer que ela seja - é o pressuposto necessário para que a crise tenha ocorrido de determinada maneira é um fato que não está em debate; que esta teria se verificado - sob uma roupagem diversa - independentemente daquela, aí reside, em última instância, a controvérsia.

Levando adiante o raciocínio da primeira corrente interpretativa é possível concluir que o que está em crise não é o sistema capitalista em si, mas a forma particular pela qual este tem evoluído. Nesse sentido, uma outra configuração política/econômica/institucional poderia ter evitado a crise recente. Assumindo, por outro lado, que a crise deriva do próprio capitalismo, de sua natureza - seja, também esta, qual for -, a turbulência deveria ocorrer, ainda que se apresentasse de outra maneira - por exemplo, iniciando-se em outro segmento que não o mercado imobiliário ou em um período diverso.

Convém destacar, por fim, que a distinção entre uma e outra abordagem não deve ser feita em termos de que a primeira trata de aspectos mais concretos e a segunda de elementos mais abstratos do sistema econômico capitalista. Se assim fosse, poderia não haver nenhuma controvérsia quanto as causas da crise, mas

\footnotetext{
${ }^{3}$ Expediente comum entre as análises sobre a literatura marxista recente. Ver, por exemplo, Choonara (2009).
} 
apenas uma diferença de foco. A distância entre as duas abordagens é, contudo, mais substantiva. Trata-se da distinção, de um lado, entre uma teoria geral da crise capitalista e, de outro, uma teoria que se aplica somente a determinados períodos de sua existência.

Seguindo a ordem cronológica de publicação das obras selecionadas, o restante deste texto está organizado da seguinte maneira. A próxima seção dedica-se ao exame dos livros de John Bellamy Foster e Fred Magdoff (2009) de David Harvey (2011), e de Gérard Duménil e Dominique Lévy (2011), que compõem o primeiro grupo. A seção seguinte sumaria o livro de Andrew Kliman (2012), que pode ser tomado como representativo da segunda corrente teórica aqui sugerida ${ }^{4}$. $\mathrm{Na}$ conclusão, fazemos breves observações.

\section{A CRISE DE UMA FASE}

\section{Foster e Magdoff (2009): A Etapa do Capital Monopolista-Financeiro ${ }^{5}$}

A tradição teórica inaugurada pela publicação, em 1966, do consagrado livro Capital Monopolista, de autoria de Paul Baran e Paul Sweezy, representa, hoje, uma daquelas três correntes mencionadas na introdução deste artigo. Veiculada, sobretudo, pela revista Monthly Review, esta abordagem, também conhecida como "Escola do Capital Monopolista”, tem sido desenvolvida e aplicada a um conjunto variado de fenômenos econômicos, entre os quais a crise recente.

A visão mais elaborada sobre o que seus autores chamam de Grande Crise Financeira, a partir dessa corrente interpretativa, encontra-se no livro The Great Financial Crisis, de John Bellamy Foster e Fred Magdoff, de 20096. Ainda que tributários da extensa literatura marxista que se desenvolve desde o final do século XIX, Foster e Magdoff (2009, p. 8) deixam clara sua inspiração nos trabalhos de Baran, Sweezy e Harry Magdoff, autores que, por sua vez, apoiaram-se fortemente em T. Veblen, J. A. Schumpeter, J. M. Keynes, M. Kalecki, J. Steindl e H. Minsky - além, evidentemente, de Marx.

Com efeito, a tentativa de examinar as causas e as consequências da Grande

\footnotetext{
${ }^{4} \mathrm{O}$ maior número de livros apresentados na primeira vertente interpretativa é sintomático do próprio peso desse conjunto de interpretações na literatura marxista de forma geral. Para maiores detalhes, ver Palludeto (2013).

${ }^{5}$ Esta seção baseia-se em Palludeto e Andrade (2014).

${ }^{6}$ Mais recentemente, esta vertente marxista passou a considerar, no tratamento da crise, um conjunto mais amplo de países no livro The Endless Crisis, de 2012, do mesmo J. B. Foster e de Robert McChesney. Além dos Estados Unidos, Foster e McChesney (2012) dedicam-se à Europa, ao Japão e àquilo que os autores denominam "Global South", com particular ênfase na China. Foster e McChesney (2012) procuram analisar a relação entre a estagnação/financeirização das economias maduras, o impacto da crise recente que nelas se verificou, entre as quais a crise europeia, e o processo de sobreacumulação no "Sul Global".
} 
Recessão proposta por Foster e Magdoff (2009) pode ser concebida como uma extensão, para a atual conjuntura, de duas obras associadas à abordagem da qual fazem parte: por um lado, conforme já indicado acima, a interpretação proposta por Baran e Sweezy (1966); por outro, o conjunto de ensaios acerca da economia mundial de Magdoff e Sweezy (1987) reunidos no livro Stagnation and Financial Explosion.

O fio condutor da análise de Foster e Magdoff (2009) é a tese de que o capitalismo que emerge a partir da segunda metade do século XIX, marcado por grandes empresas organizadas tipicamente sob a forma de sociedade por ações, apresenta uma tendência permanente à estagnação. Nas palavras dos autores: "Stagnation, of course, does not mean that there is no growth whatsoever. Rather, the economy functions well below its potential - with appreciable unused productive capacity and significant unemployment and underemployment" (Foster e Magdoff, 2009, p. 39).

Por um lado, tem-se o crescente potencial produtivo da sociedade, possibilitado pelo próprio movimento de concentração e centralização do capital e o desenvolvimento tecnológico que a ele se associa - processos que se encontram na origem do surgimento e consolidação das grandes empresas. Por outro, os níveis de consumo e investimento são insuficientes para absorver o crescente excedente econômico ${ }^{7}$ gerado por essa forma de organização da produção. A estagnação, portanto, é concebida como o estado normal de uma economia na qual há uma tendência ao crescimento do excedente (Baran e Sweezy, 1966, cap. 3) e, simultaneamente, uma capacidade limitada para absorvê-lo - sobretudo pela ausência de oportunidades rentáveis de investimento (Foster e Magdoff, 2009, p. 39). Baixo crescimento econômico agregado, crescente excesso de capacidade produtiva e altos níveis de desemprego/subemprego convertem-se, assim, nos traços fundamentais do capitalismo monopolista.

Dessa forma, momentos de prosperidade, como aqueles do imediato pós-Segunda Guerra, período tradicionalmente conhecido como a Era de Ouro do capitalismo, são exceções e devem ser compreendidos a partir dos meios pelos quais o excedente foi absorvido (ou realizado). De acordo com Foster e Magdoff (2009), em uma argumentação que reproduz, quase que ipsis litteris, Baran e Sweezy (1966), a tendência à estagnação é - e o foi historicamente - acompanhada por uma série de contra-tendências, capazes de conferir dinamismo temporário à economia ao

\footnotetext{
${ }^{7}$ O excedente econômico (economic surplus) é definido por Baran e Sweezy (1966, p. 112) como "the difference between total social output and the socially necessary costs of producing it". A sugestão do uso desta categoria, em substituição à mais-valia (surplus-value) de Marx, levou diversos autores, também reconhecidos no meio acadêmico marxista, a questionar sua validade teórica: "The substitution has been made because Baran and Sweezy have switched from Marxian to bourgeois economic analysis, which does not operate with class terms such as value and surplus-value but with the amalgam national income, the concept of 'effective demand', and the Keynesian remedies for capital stagnation. It would indeed be a strange kind of 'Marxism' which paid more attention to the distribution of surplus-value among the capitalists and their retainers than to the division of the social product between labour and capital” (Mattick, 1978, p. 191).
} 
servirem de escoadouro ao excedente não absorvido. Entre as principais, destacamse, por um lado, a combinação do desenvolvimento de novas tecnologias, produtos e a elevação do dispêndio em esforço de vendas (marketing, por exemplo); e, por outro, o crescimento dos gastos do governo nas diversas esferas da administração pública e, sobretudo, na área militar. No entanto, ainda que possam permitir períodos de relativo vigor econômico, esses fatores são limitados:

[...] growth of civilian government spending was strictly limited by the fact that it tended to intrude on areas of private accumulation. Military spending needed to be justified in terms of some external threat, and hence could only go so far. The sales effort was only rational at the level of the firm insofar as it translated into additional sales and increased market share. [...] While the stagnation tendency was deeply rooted, powerful and persistent, the countervailing tendencies were more superficial, weaker and self-limiting (Foster e Magdoff, 2009, pp. 65-66).

O foco na insuficiência crônica de demanda e, sobretudo, na necessidade de estímulos externos ao processo de valorização do capital para que o crescimento econômico seja possível fez com que a abordagem da Escola do Capital Monopolista fosse considerada uma nova versão da já conhecida tese do subconsumo - criticada com veemência por muitos marxistas desde o final do século XIX. Por exemplo, segundo Shaikh (1978), os subconsumistas argumentam que "the capitalist system is incapable of self-expansion. It must grow to survive, but it requires some external source of demand (like the non-capitalist world) in order to keep it growing. This means that its reproduction is ultimately regulated by factors outside of the system: the limits to the system are external to it" (Shaikh, 1978, p. 220). Por essa razão, Shaikh (1991, p. 161) argumenta que, em vez de uma teoria da necessidade da crise capitalista, os subconsumistas/estagnacionistas defendem uma teoria da possibilidade da crise, a qual ocorre se e quando se verifica uma particular combinação de fatores históricos ${ }^{8}$.

Segundo os autores, o capitalismo contemporâneo caracteriza-se por uma nova e poderosa forma de absorção do excedente - apenas sugerida en passant por Baran e Sweezy (1966), mas desenvolvida com profundidade por Magdoff e Sweezy (1987): as finanças'. De acordo com Foster e Magdoff (2009), este processo de "autonomia das finanças em relação à produção" desenrola-se da seguinte forma:

\footnotetext{
${ }^{8}$ Para um aprofundamento desta crítica, ver Shaikh (1991). Para uma defesa da Escola do Capital Monopolista às diversas críticas que, graças ao seu reconhecido viés subconsumista, ao longo do tempo lhe foram dirigidas, ver Foster (1986).

9 "Far from failing to even 'hint' at the role of finance, Monopoly Capital had included at the very end of the chapter on 'The Sales Effort' a separate section on the role of the finance sector as an outlet for surplus absorption, arguing that this was 'on an equal footing with the sales effort'" (Foster e Magdoff, 2009, pp. 68-69).
} 
Unable to find profitable outlets for their investment-seeking surplus within the productive economy, corporations/capitalists sought to augment their money capital by means of financial speculation, while the financial system in its turn responded to this increased demand for its "products" with a bewildering array of new financial instruments - including stock futures, options, derivatives, hedge funds etc. The result was the rise by the 1980s of a financial superstructure that increasingly took on a life of its own (Foster e Magdoff, 2009, p. 72).

$\mathrm{O}$ redirecionamento do excedente para as atividades financeiras e o maior peso relativo que estas adquiriram nas últimas décadas correspondem ao processo que os autores denominam de financeirização: a mudança do centro de gravidade da economia da produção para as finanças, traço distintivo do sistema capitalista moderno (Foster e Magdoff, 2009, p. 18). Tamanha é a importância atribuída ao fenômeno, que são levados a sugerir que o capitalismo mundial entrou, a partir de então, em uma nova fase de seu desenvolvimento, marcada pela combinação de estagnação e financeirização. Segundo os autores, o capitalismo monopolista cedeu lugar, nas últimas décadas, ao capitalismo monopolista-financeiro (Foster e Magdoff, 2009, cap. 3).

Embora estejam cientes de que a rápida expansão do crédito, fruto do acelerado desenvolvimento das atividades financeiras, foi um dos mais importantes fatores que contrabalançaram a tendência à estagnação no período recente, sobretudo pelo consumo, como contrapartida ao baixo crescimento dos salários reais, Foster e Magdoff (2009) constatam que boa parte desses recursos voltou-se para a própria esfera financeira:

[B]allooning of finance produced new outlets for surplus in the finance, insurances, and real estate (FIRE) sector of GDP in the form of new investment in buildings, office, equipment etc. Nevertheless, the great bulk of the money capital devoted to finance was used for speculation in securities, real estate, and commodities markets rather than for investment in capital goods, and thus did not feed into the growth of GDP, which continued to stagnate (Foster e Magdoff, 2009, p. 67).

Nesse sentido, três principais aspectos acabaram por definir esta nova etapa do capital monopolista-financeiro:

(1) The stagnation of the underlying economy meant that capitalists were increasingly dependent on the growth of finance to preserve and enlarge their money capital. (2) The financial superstructure of the capitalist economy could not expand entirely independently of its base in the underlying productive economy - hence the bursting of speculative bubbles was a recurrent and growing problem. (3) Financialization, no matter how far it extended, could never overcome stagnation within production (Foster e Magdoff, 2009, p. 83). 
A relativa autonomização das atividades financeiras, ainda que funcional como meio de absorção do excedente, representou, portanto, uma fonte de instabilidade adicional a um capitalismo cuja esfera produtiva já se encontrava debilitada. As sucessivas bolhas que marcaram a história recente dos Estados Unidos são, desse modo, manifestações necessárias da tensão permanente entre a estagnação produtiva e a explosão financeira.

De acordo com os autores, a crise recente resulta da dinâmica inerente a essa nova fase do capitalismo, fruto da estagnação latente e da instabilidade gerada pelo setor financeiro, cujo crescimento acelerado se deve à própria estagnação econômica. O descompasso entre o inexpressivo crescimento da renda agregada, em particular dos salários reais ${ }^{10}$, e a proliferação de ativos financeiros diversos encontrou na crise, na incapacidade da economia real validar as crescentes demandas da esfera financeira, sua expressão máxima. Por conseguinte, concluem os autores, "both the financial explosion in recent decades and the financial implosion now taking place are to be explained mainly in reference to stagnation tendencies within the underlying economy" (Foster e Magdoff, 2009, p. 120).

Embora considerem a crise recente fruto da dinâmica de uma fase específica do sistema capitalista, os autores sugerem que resolver definitivamente os problemas gerados pela atual etapa do capital monopolista-financeiro significa superar o próprio capitalismo enquanto forma de organização da produção, algo que, como não poderia deixar de ser vindo de autores marxistas, inscreve-se na esfera da ação política: "it is necessary for the population to seize control of their political economy, replacing the present system of capitalism with something amounting to a real political and economic democracy; what the present rulers of the world fear and decry most - as ‘socialism'” (Foster e Magdoff, 2009, pp. 139-140).

\section{Harvey (2011): O “Enigma” da Crise Econômica Recente ${ }^{11}$}

David Harvey, um dos mais conhecidos expoentes do marxismo contemporâneo, é também um dos principais intérpretes da crise recente. Sua visão acerca das causas desta encontra-se no livro The Enigma of Capital, de 2010.

Conforme o próprio título da obra sugere, o autor procura desvendar a lógica de operação do capital e, assim, compreender as crises que dela fatalmente derivam. Não se trata, portanto, de um livro que se dedica exclusivamente à crise atual. $\mathrm{Na}$ verdade, Harvey (2011) propõe uma interpretação peculiar do modo de funcionamento do sistema capitalista, a partir da qual, aí sim, busca tornar inteligível a crise recente.

O argumento do autor centra-se na concepção do capital como um fluxo, um processo contínuo no qual o detentor da riqueza, o capitalista, lança mão de seu

\footnotetext{
10 "A key element in explaining this whole dynamic is to be found in the falling ratio of wages and salaries as a percentage of national income in the United States" (Foster e Magdoff, 2009, p. 129).

${ }^{11}$ Esta seção baseia-se em Andrade e Palludeto (2013).
} 
dinheiro para ganhar mais dinheiro: "Capital is not a thing but a process in which money is perpetually sent in search of more money" (Harvey, 2011, p. 40). Embora esse movimento possa assumir várias formas distintas, Harvey sustenta que o modo de circulação do capital industrial, dominante desde meados do século XVIII, é o mais adequado para a compreensão da dinâmica capitalista. Com efeito, a conversão perpétua de dinheiro em mão de obra, matérias-primas e máquinas para a produção de mercadorias cuja venda remunere adequadamente o capital despendido e, assim, permita um lucro que se agregue a esse circuito - ou seja, a própria acumulação de capital - é, para o autor, o processo que confere movimento à economia capitalista. Embora não explicitada pelo autor, a dinâmica à qual Harvey se refere é, na verdade, aquela sintetizada por Marx (1885) na conhecida fórmula:

$$
D-M<\underset{M p}{F} \ldots P \quad \ldots M^{\prime}-D^{\prime}
$$

onde $\mathrm{D}$ representa o volume de dinheiro avançado como capital, $\mathrm{M}$ as mercadorias necessárias ao processo produtivo (decompostas em $\mathrm{F}$, a força de trabalho, e Mp, os meios de produção), $P$ representa o processo produtivo, $M^{\prime}$ as mercadorias produzidas (acrescidas em valor na produção), e $D^{\prime}$ o dinheiro auferido pelas vendas das mercadorias, cujo valor, em virtude do lucro, é maior do que o valor do capital original, D.

Segundo Harvey (2011, p. 28), as evidências históricas da economia mundial sugerem que a continuidade do processo de acumulação de capital, ou seja, a aplicação contínua do lucro como capital, exige uma taxa de crescimento anual mínima da produção agregada em torno de 3\%. Nesse patamar (ou acima dele), os lucros seriam satisfatórios e os capitalistas encontrariam oportunidades rentáveis para sua massa de riqueza ampliada. Por outro lado, um crescimento abaixo dessa taxa corresponderia a uma interrupção do processo de acumulação de capital e, como resultado, uma crise teria lugar, desvalorizando o capital ${ }^{12}$.

Se as crises representam, portanto, a incapacidade de o processo de acumulação capitalista prosseguir, ou seja, a suspensão do movimento de expansão da riqueza privada, quais suas possíveis causas? Em outras palavras, quais os empecilhos à acumulação de capital?

Harvey sugere que existem seis obstáculos à reprodução ampliada do capital:

Examination of the flow of capital through production reveals six potential barriers to accumulation that have to be negotiated for capital to be reproduced: i) insufficient initial money capital; ii) scarcities of, or political difficulties with, labour supply; iii) inadequate means of

\footnotetext{
12 Harvey chega a afirmar que a própria existência do capitalismo encontra-se ameaçada caso não se atinja essa cabalística taxa de crescimento: "No matter what innovation or shift occurs, the survival of capitalism in the long run depends on the capacity to achieve 3 per cent compound growth" (Harvey, 2011, p. 130).
} 
production, including so-called "natural limits"; iv) inappropriate technologies and organisational forms; v) resistance or inefficiencies in the labour process; and vi) lack of demand backed by money to pay in the market. Blockage at any one of these points will disrupt the continuity of capital flow and, if prolonged, eventually produce a crisis of devaluation (Harvey, 2011, p. 47).

Note que cada uma dessas barreiras pode ser facilmente associada a um dos momentos particulares do processo de acumulação de capital sintetizado na fórmula anteriormente apresentada:

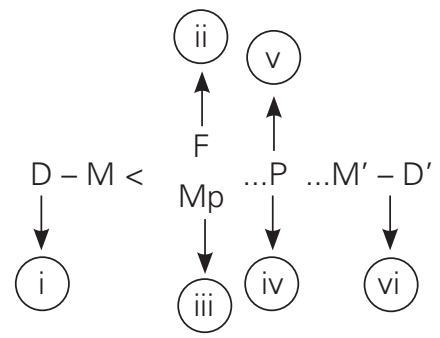

Não é difícil observar que Harvey compartilha, no tratamento desse tema, da interpretação de Marx proposta por Ernest Mandel (1975), que rejeita a tese de que as crises econômicas no capitalismo tenham uma causa exclusiva ${ }^{13}$. A crise pode resultar de qualquer um dos elementos acima identificados, bem como de uma eventual combinação deles. À falta de mão de obra pode se associar limitações tecnológicas ou no processo de trabalho; a insuficiência de capital-dinheiro pode se unir à falta de demanda, etc.

Ademais, o autor não afirma que exista a primazia de tal ou qual barreira. Os obstáculos à acumulação de capital são potenciais e, por conseguinte, somente a análise da forma particular assumida pelo capitalismo em dado contexto histórico poderá revelar qual (ou quais) dessa(s) barreira(s) foi (ou foram) determinante(s). Nos termos propostos por Shaikh (1991), pode-se afirmar que Harvey possui, portanto, uma teoria da possibilidade da crise - e não uma teoria da necessidade da crise, em virtude, por exemplo, de uma inexorável tendência à queda da taxa de lucro.

De fato, Harvey parece bastante descrente quanto à validade da lei da queda tendencial da taxa de lucro tal como apresentada por Marx (1894, cap. 13). Ainda que não se aprofunde no tema, Harvey adota, implicitamente, uma perspectiva muito semelhante à de Paul Sweezy (1942, cap. 6) quando sugere que o sentido da taxa de lucro associada às inovações tecnológicas poupadoras de mão de obra - ou, na terminologia marxista, à elevação da composição orgânica do capital, isto é, da relação entre o capital constante e o capital variável - parece indeterminada:

\footnotetext{
13 "Marx explicitly rejects any monocausal explanation of crises, insisting that they are a combination of all the contradictions of the capitalist mode of production" (Mandel, 1975, p. 438).
} 
[...] it is hard to make Marx's theory of the falling rate of profit work when innovation is as much capital or means of production saving (through, for example, more efficient energy use) as it is labour saving. Marx himself actually listed a variety of counteracting influences to a falling rate of profit, including rising rates of exploitation of labour, falling costs of means of production (capital-saving innovations), foreign trade that lowered resource costs, a massive increase in the industrial reserve army of labour that blunts the stimulus for the employment of new technologies, along with the constant devaluation of capital, the absorption of surplus capital in the production of physical infrastructures, as well as, finally, monopolisation and the opening up of new labourintensive lines of production. This list is so long that it renders the neat explanation for a solid "law" of falling profits as a mechanical response to labour-saving technological innovation more than a little moot (Harvey, 2011, p. 94).

Não é por outra razão que a elevação da composição orgânica do capital - e o suposto declínio da taxa de lucro dela resultante - não está figurada entre as possíveis causas das crises econômicas, embora essa hipótese seja bastante difundida entre os autores marxistas que se dedicam a teorizar sobre as crises capitalistas.

Em linhas gerais, essa é a construção teórica de que se vale Harvey na tentativa de elucidar a crise recente. O ponto de partida de sua análise são os efeitos da turbulência pela qual passou a economia mundial, particularmente a norte-americana, ao final da década de 1960 e no decorrer dos anos 1970, bem como o papel desempenhado aí por sindicatos fortes. Conforme argumenta o autor,

One of the major barriers to sustained capital accumulation and the consolidation of capitalist class power back in the 1960s was labour. There were scarcities of labour in both Europe and the US. Labour was well organised, reasonably well paid and had political clout (Harvey, 2011, pp. 12-14).

Ao pressionar os lucros da classe capitalista, os trabalhadores tornaram-se um entrave à reprodução ampliada do capital no período. A superação da crise dos anos 1970 deu-se, no entanto, através da adoção de políticas neoliberais, de inovações poupadoras de mão de obra, de maior permissividade às imigrações e da inclusão de massas crescentes de trabalhadores ao mercado mundial, particularmente da Ásia. Com isso, tornou-se viável solucionar o problema dos altos custos da mão de obra que deu origem à crise. Como resultado desse processo, segundo Harvey (2011, p. 15), a disponibilidade de mão de obra deixou de ser uma barreira para o capital durante as últimas três décadas e os salários reais estagnaram, sobretudo na economia norte-americana.

Contudo, se a solução para a crise no período passou pelo fortalecimento da classe capitalista - e consequente pressão sobre os salários e, assim, a eleva- 
ção do lucro -, o mesmo fenômeno criou outro obstáculo à acumulação de capital, barreira essa que, em última instância, levou à crise recente: a falta de demanda. De um lado, a estagnação dos salários reais reduziu a demanda da classe trabalhadora; de outro, colocou nas mãos dos capitalistas uma massa crescente de lucro sem, no entanto, nenhuma garantia de que esta pudesse encontrar oportunidades vantajosas de investimento. Ao declínio da demanda dos trabalhadores combinou-se, por conseguinte, uma demanda insuficiente por parte dos capitalistas. Harvey (2011, p. 26) denomina esse fenômeno - que, segundo ele, está na raiz da crise contemporânea - como o "problema da absorção do capital excedente", isto é, a ausência de aplicações rentáveis para o volume crescente de lucro, ou a falta de investimentos lucrativos que pudessem absorver os recursos excedentes dos capitalistas.

Nesse contexto de enfraquecimento da demanda, associado ao "excesso de capital", é que tem origem a financeirização, que, de acordo com o autor, é um dos traços fundamentais das últimas décadas e constitui o elemento deflagrador da crise recente. A financeirização, entendida como o crescimento acelerado não só do montante de operações financeiras, mas também de instrumentos e agentes financeiros, foi um imperativo da evolução do capitalismo desde os anos 1970. De um lado, o crédito farto pôde sustentar o consumo dos trabalhadores, a despeito da estagnação dos salários reais; de outro, as aplicações financeiras mostraram-se uma saída para o excesso de capital ${ }^{14}$. O rápido crescimento da alavancagem e da especulação e, portanto, a construção de estruturas financeiras frágeis, foram resultados desse movimento. A formação e o colapso da bolha no mercado imobiliário norte-americano, a causa imediata da crise, foram as manifestações mais recentes do processo de financeirização.

No entanto, ainda que o direcionamento de recursos para as atividades financeiras, a explosão do crédito e a bolha que a partir daí teve origem cumpram seus papéis na explicação da crise recente, é forçoso reconhecer, conforme já destacado acima, que, para Harvey, todo esse processo que culmina na Grande Recessão tem como determinante o problema de absorção do capital excedente - ou seja, em última instância, à falta de demanda. Destarte, para o autor, o modo encontrado para a saída da crise da década de 1970 , ou seja, a pressão sobre a classe trabalhadora - e, por conseguinte, a elevação dos lucros na participação da renda - é a causa subjacente da crise recente. Para usar uma imagem familiar, é como se, para Harvey (e outros marxistas), nos anos 1970 tivessem sido originalmente plantadas as "sementes da destruição" da forma específica assumida pelo capitalismo da primeira década do século XXI, o capitalismo neoliberal.

\footnotetext{
14 Como visto, o mesmo tipo de argumento aparece na linhagem marxista que se inspira no livro
} Capitalismo Monopolista, de Baran e Sweezy (1966). Ver, e.g., Foster e Magdoff (2009, p. 72). 


\section{Duménil e Lévy (2011): A "Grande Contração" de 2007-09 como uma Crise do Neoliberalismo ${ }^{15}$}

Outra das principais referências entre os autores de inspiração marxista sobre a crise contemporânea são os trabalhos de Gérard Duménil e Dominique Lévy. O tema é tratado extensa e intensivamente pelos autores no livro The Crisis of Neoliberalism, publicado em 2011.

Para Duménil e Lévy (2011), a causa última da crise recente não reside num suposto declínio da taxa de lucro e tampouco na falta de demanda resultante da estagnação dos salários reais a partir dos anos 1970. Os autores sustentam que a turbulência contemporânea é fruto da dinâmica do que consideram uma ordem social particular: o neoliberalismo, "the latest of three social orders, which jointly constitute modern capitalism, that is, capitalism since the turn of the twentieth century" (Duménil e Lévy, 2011, p. 7).

Ao se debruçarem sobre a história do capitalismo, Duménil e Lévy (2011) observam que a partir da Grande Depressão da década de 1890 ocorreram importantes transformações na economia norte-americana. Segundo os autores, a conjugação de três revoluções acabou por ditar o rumo do sistema capitalista desde então:

1) a revolução da grande empresa (corporate revolution), ou seja, a difusão das sociedades por ações, como forma de organização empresarial;

2) a revolução financeira, ou seja, o crescimento do sistema bancário e as relações de suporte e dominação que estabeleciam com as corporações então nascentes;

3) e, por fim, a revolução gerencial, isto é, a partir da disseminação das sociedades por ações, a formação de uma classe de administradores profissionais e assalariados cuja função exclusiva é gerir o empreendimento capitalista ${ }^{16}$.

Como resultado dos três fenômenos acima descritos, mais do que a posse direta dos meios de produção, a riqueza de uma fração crescente da classe capitalista passou, cada vez mais, a se materializar na propriedade de títulos financeiros diversos - em particular, as ações. Desse modo, as instituições financeiras, instrumentos por meio dos quais essa riqueza sob a forma de papéis é gerida e boa parte do crédito, fornecido, tornaram-se um dos elementos centrais do sistema capitalista moderno.

\footnotetext{
${ }^{15}$ Esta seção baseia-se em Palludeto (2013).

${ }^{16} \mathrm{O}$ processo de difusão da sociedade por ações corresponde, de fato, à crescente separação entre a gestão e a propriedade. Com a sociedade por ações, o capitalista, proprietário da riqueza, não se confunde mais com o administrador dos recursos da empresa. Nesse arranjo institucional particular, o capitalista é um acionista e a gerência da empresa é delegada a um grupo de administradores profissionais. No tratamento dessa questão, Duménil e Lévy (2011) seguem, ainda que implicitamente, uma extensa literatura cuja referência básica é o trabalho de Adolf Berle e Gardiner Means (1932).
} 
Com o intuito de enfatizar o caráter financeiro do capitalismo moderno, os autores utilizam o termo "Finanças" para caracterizar essa nova etapa do desenvolvimento capitalista. Este termo refere-se ao seguinte:

the upper fractions of capitalist classes and to financial institutions in any social arrangement in which these fractions of capitalist classes control financial institutions (as is generally the case in capitalism) (Duménil e Lévy, 2011, p. 13).

Em outras palavras, as Finanças fazem alusão às instituições financeiras e à fração da classe capitalista que as controlam, que são, em geral, segundo os autores, os extratos superiores dessa classe. Assim, de acordo com esta definição, as "Finanças" não são apenas um setor distinto da economia, mas compreendem, também, as frações da classe capitalista que controlam esse segmento. O termo Finanças, portanto, combina aspectos institucionais e de classe (Duménil e Lévy, 2011, p. 13).

A partir dessas observações, os autores sustentam que uma caracterização mais adequada da estrutura de classes prevalecente no capitalismo moderno não mais seria aquela que contrapõe, de um lado, a classe trabalhadora e, de outro, a classe capitalista, mas, sim, uma configuração tripolar, composta por: i) a classe capitalista; ii) a classe gerencial; iii) a classe popular (Duménil e Lévy, 2011, p. 14).

A classe trabalhadora estaria subdividida em dois grupos: de um lado, a classe gerencial, composta da alta cúpula administrativa das grandes corporações, segmento que aufere os maiores salários e benefícios, e cuja origem se encontra, como já visto, na revolução gerencial; de outro, a classe popular, constituída dos demais trabalhadores.

Com base nessas categorias, os autores sugerem que existem três ordens sociais distintas na história do capitalismo moderno, de acordo com a relação de poder e a consequente rede de alianças que se estabelecem entre essas três classes. O critério básico que define a periodização da história econômica recente é a configuração de poder que essa estrutura de classes apresenta a cada momento. É com base nesse critério que Duménil e Lévy (2011) especificam a sucessão de três ordens sociais no capitalismo moderno.

Do início do século XX até a Grande Depressão da década de 1930 vigorou aquilo que os autores denominam a "primeira hegemonia financeira". De modo geral, o período caracterizou-se pelo compromisso entre a classe capitalista, particularmente a parcela que compõe as Finanças, e a classe gerencial. Contudo, a partir do New Deal e da Segunda Guerra Mundial, uma nova ordem social se instaurou. Surge então o "compromisso do pós-guerra" ou "compromisso keynesiano", um arranjo político-institucional que representou o fortalecimento da classe trabalhadora em aliança com a classe gerencial.

Com a crise da década de 1970, no entanto, o compromisso keynesiano entrou em colapso e, em seu lugar, o neoliberalismo tornou-se a ordem social vigente. Segundo os autores, o neoliberalismo representa uma nova aliança entre a classe gerencial e a classe capitalista, em oposição à classe popular, e manifesta-se, por- 
tanto, como uma "segunda hegemonia financeira". A contenção do poder de compra dos trabalhadores e o crescimento da participação do setor financeiro na economia são, de acordo com Duménil e Lévy (2011), duas das principais características do período.

A transição de uma ordem social para outra ou, ainda, de uma fase do sistema capitalista moderno para outra é marcada pelo que os autores denominam crises estruturais. Enquanto as crises das décadas de 1890 e de 1970 são crises de rentabilidade, a Grande Depressão e a turbulência recente, batizada de crise do neoliberalismo, são crises da hegemonia financeira.

Se a crise recente tem como causa última, tal como argumentam os autores, as contradições inerentes à estratégia da classe capitalista - em aliança com a classe gerencial - para ampliar sua renda e riqueza, isto é, à própria dinâmica do que definem como neoliberalismo, em que elas consistem? Vale dizer, quais as contradições dessa nova fase do sistema capitalista que levaram à Grande Recessão de 2007-09?

Como o neoliberalismo representa uma segunda hegemonia das Finanças, materializada na aliança entre as frações mais elevadas da classe capitalista e da classe gerencial, um dos primeiros aspectos destacados é a financeirização da economia, que, para os autores, corresponde ao crescimento acelerado do volume de ativos financeiros - não apenas daqueles já existentes como, sobretudo, de novos instrumentos. Ademais, se a busca por altos rendimentos por parte das classes mais elevadas, objetivo que, segundo Duménil e Lévy (2011), caracteriza o neoliberalismo, levou ao processo de financeirização, também implicou a globalização da economia capitalista. Em outras palavras, o novo arranjo social estabelecido a partir das décadas de 1970-1980, além da ampliação do setor financeiro, teve como consequência impulsionar a expansão global das grandes corporações, particularmente direcionadas ao Leste Asiático, e dos fluxos financeiros em geral.

Outro elemento apontado pelos autores é a trajetória macroeconômica dos Estados Unidos. De acordo com Duménil e Lévy (2011), as baixas taxas de investimentos nas últimas décadas e os crescentes déficits no balanço de pagamentos em transações correntes no período tornaram ainda mais propícias as condições para a crise. Por um lado, o fraco desempenho da acumulação de capital e a estagnação dos salários reais fez com que o crescimento econômico norte-americano dependesse cada vez mais do afrouxamento da política monetária e do endividamento das famílias. Por outro, o aumento do consumo refletia-se em maiores importações que, por sua vez, ampliava os desequilíbrios da economia e a necessidade de financiamento externo em volumes progressivamente maiores.

Desse modo, os autores sustentam que, a despeito do sucesso da estratégia neoliberal em aumentar os rendimentos das classes mais elevadas, fenômeno observável pelo aumento da desigualdade de renda tanto no interior destas, como entre estas e as classes populares, e pela recuperação da taxa de lucro, os meios utilizados para atingi-lo engendraram uma estrutura financeira frágil e suscetível a variações bruscas nos preços dos ativos.

A crise do mercado imobiliário foi apenas o estopim, a causa imediata da 
Grande Recessão, denominada por Duménil e Lévy (2011) de “Grande Contração”. Sua causa última reside na dinâmica contraditória do neoliberalismo, na estratégia da classe capitalista em aliança com a classe gerencial para elevar ao máximo os seus rendimentos. As políticas neoliberais, a crescente financeirização da economia, o movimento de globalização recente, o fraco desempenho econômico dos Estados Unidos, o déficit em transações correntes e o elevado endividamento interno e externo são os fatores, direta ou indiretamente relacionados àquela estratégia, que, conjuntamente, levaram à crise. Se, por um lado, as Finanças, mediante compromisso com a classe gerencial, foi capaz de ampliar seus rendimentos e, simultaneamente, a participação do setor financeiro na economia, por outro, foram os elementos responsáveis por esse sucesso que acabaram por criar uma situação econômica insustentável. Assim, a crise recente é fruto, em última instância, dessa ordem social particular e, segundo os autores, marca seu fim, caracterizando-se, portanto, como uma crise estrutural.

\section{UMA CRISE CAPITALISTA}

\section{Kliman (2012): A Lei de Tendência à Queda da Taxa de Lucro como Manifestação Histórica}

Ao contrário do debate marxista sobre as causas da crise da década de 1970, que, grosso modo, girou em torno dos fatores determinantes da queda da taxa de lucro e não na queda em si - sobre a qual havia um relativo consenso -, não é este, como já se pôde observar, o tom das discussões sobre a Grande Recessão. Enquanto os estudos anteriores têm negado que a taxa de lucro da economia norte-americana tenha apresentado uma trajetória declinante ao longo das últimas décadas, esse é precisamente o argumento de Andrew Kliman (2012), em seu livro The Failure of Capitalist Production: Underlying Causes of the Great Recession ${ }^{17}$.

Neste sentido, é o caso de indagar: qual a origem de tamanha divergência? Seria apenas o resultado de um método de mensuração distinto ou refletiria alguma diferença teórica mais profunda?

De fato, trata-se de uma importante distinção teórica que se expressa no modo de mensuração da taxa de lucro, particularmente quanto ao estoque de capital. Aqui se confrontam duas interpretações distintas sobre a teoria marxista do valor, particularmente sobre aquilo que ficou conhecido na literatura como o "problema da transformação" ${ }^{18}$. De um lado, aquela que se pode considerar a interpretação

\footnotetext{
${ }^{17} \mathrm{Na}$ verdade, esse livro é uma atualização e extensão de outro estudo do autor sobre a crise recente; ver Kliman (2010).

18 "Problema da transformação" é a expressão, talvez inapropriada, geralmente utilizada para se referir ao debate acerca do procedimento exposto por Marx (1894, cap. 9) para demonstrar a passagem dos valores aos preços de produção, isto é, ao conjunto de preços que garantiria a mesma taxa de lucro a
} 
convencional, cuja formalização se baseia em equações simultâneas, e, de outro, a interpretação do "sistema único temporal" (ISUT) - do inglês, Temporal Single-System Interpretation.

Em linhas bastante gerais, de acordo com a interpretação convencional, Marx (1894), ao expor o modo pelo qual se daria a passagem dos valores aos preços de produção, cometeu um grave equívoco ao não considerar que também os insumos (capital constante e variável) devessem passar pelo mesmo procedimento. Segundo essa abordagem, o próprio Marx teria reconhecido o suposto erro, sem, contudo, dar a ele a devida importância em relação à modificação que seria necessária aos resultados de sua análise:

It was originally assumed that the cost price [i.e.,, a soma do capital constante e variável] of a commodity equalled the value of the commodities consumed in its production. But for the buyer of a commodity, it is the price of production that constitutes its cost price and can thus enter into forming the price of another commodity. As the price of production of a commodity can diverge from its value, so the cost price of a commodity, in which the price of production of other commodities is involved, can also stand above or below the portion of its total value that is formed by the value of the means of production going into it. It is necessary to bear in mind this modified significance of the cost price, and therefore to bear in mind too that if the cost price of a commodity is equated with the value of the means of production used up in producing it, it is always possible to go wrong (Marx, 1894, pp. 264-265).

A correção que se fez do modelo apresentado por Marx (1894) baseou-se não em um processo iterativo, sequencial (como parecia ser sua sugestão), mas na construção de um modelo de determinação simultânea, no qual os valores/preços dos insumos são iguais, por definição, aos valores/preços do produto. Como resultado, firmou-se na literatura a ideia de que valores e preços são dois sistemas paralelos, cuja relação, se existir, deve ser estabelecida por meio da resolução de um conjunto de equações simultâneas.

As conclusões obtidas por meio desse método, no entanto, divergiram daquelas às quais Marx (1894) havia chegado: a soma dos preços não correspondia à soma dos valores; o lucro total não era idêntico à mais-valia total; e, por fim, a taxa de lucro média em valor era distinta da taxa de lucro média obtida pelo sistema de preços. Uma ou outra dessas igualdades agregadas poderia ser mantida, mas apenas à custa das demais. Em outras palavras, a dimensão quantitativa da teoria

todos os capitais individuais. Se, por um lado, as duas amplas abordagens destacadas neste trabalho estão longe de representar os inúmeros apontamentos que o tema suscitou - e ainda suscita -, por outro, são suficientes para os propósitos deste estudo. Da mesma forma, a fim de facilitar a exposição, as conclusões de cada uma dessas duas interpretações não são rigorosamente demonstradas, mas apenas apresentadas. Para maiores detalhes sobre o tema, ver Kliman (2007) e Saad-Filho (2002). 
do valor de Marx, segundo essa perspectiva, mostrou-se logicamente inconsistente, uma vez que o sistema de preços não podia ser obtido integralmente por meio do sistema de valores.

Não menos importante, quando aplicado à questão dos valores/preços, o método simultâneo indicava que o trabalho, enquanto substância do valor, não cumpria nenhuma função na determinação dos preços e da taxa de lucro, pois estes poderiam ser obtidos diretamente por meio das quantidades físicas dos insumos e dos produtos. Dessa forma, a teoria do valor de Marx não apenas carecia de consistência lógica como, ademais, seria completamente desnecessária para que se determinassem o sistema de preços e a taxa de lucro correspondente.

De acordo com Kliman (2007) e Carchedi (2011), essa tradição teórica, cuja referência básica é o estudo de Bortkiewicz (1907), passa por Sraffa (1960) e atinge sua maior expressão em Steedman (1977), que afirma o seguinte:

In doing so [a transformação], however, one finds that, in general, profits and prices cannot be derived from the ordinary value schema, that $\mathrm{s} /(\mathrm{c}+\mathrm{v})$ [mais-valia, s, sobre o capital total, constante, c, mais variável, $v]$ is not the rate of profit and that total profit is not equal to total surplus value. Thus not only can one build the theory of profits and prices around the physical schema, rather than the value schema, but one is forced to do so (Steedman, 1977, pp. 47-48).

Outro ponto da teoria de Marx (1894) rejeitado pela interpretação convencional é a própria lei de tendência à queda da taxa de lucro, considerada pelo autor "the most important law of modern political economy" (Marx, 1957-58, p. 748). Inspirado pela obra de Sraffa (1960), Okishio (1961) foi capaz de provar matematicamente que a introdução de inovações técnicas, dado o nível de salário real, ao elevar a produtividade, ainda que reduzindo a proporção do capital variável em relação ao capital constante, reflete-se em uma taxa média de lucro maior, e não menor, como apontava Marx (1894). Afinal, se a remuneração do trabalhador for, de fato, considerada constante e o preço dos insumos for idêntico ao preço dos produtos, a taxa de lucro, sendo, dessa forma, um mero excedente físico, jamais declinará com o aumento da produtividade. O Teorema de Okishio, como ficou conhecida a proposição acima, teve grande impacto sobre os estudiosos marxistas, sobretudo por desacreditar a lei de tendência à queda da taxa de lucro como uma hipótese teórica válida para a análise das crises.

Em contraposição à abordagem convencional, a ISUT procura demonstrar como a inconsistência lógica atribuída à dimensão quantitativa da teoria do valor de Marx não deriva dela mesma, mas da forma com que foi interpretada ao longo do século XX. Desse modo, caberia rejeitar não a teoria do valor proposta por Marx, mas as interpretações que a tornam inconsistente e irrelevante. A própria forma pela qual a abordagem foi chamada pelos seus proponentes fornece indícios de como essa interpretação se diferencia da anterior. Primeiro, ela busca caracterizar um processo que ocorre ao longo do tempo histórico. Em outras palavras, a 
transformação dos valores em preços de produção é um movimento contínuo, que se manifesta a cada período e não de uma única vez. Segundo, preços e valores não são concebidos como dois universos ou sistemas paralelos - de tal modo que teremos sempre duas formas de determinação das taxas de lucro e das relações de troca entre as mercadorias - cuja vinculação, como se viu, é pouco provável, se não impossível, nos termos propostos pela interpretação convencional.

Ao sustentar que os preços dos insumos podem (e, em geral, irão) ser diferentes dos preços dos produtos e que valor e preço, embora distintos, se determinam mutuamente ao longo do tempo, de tal forma que o valor do capital adiantado depende do preço de seus componentes e não do valor originalmente despendido na produção destes, em um movimento iterativo, de codeterminação, a ISUT foi capaz de remover as principais críticas ao aspecto quantitativo da teoria do valor de Marx. Conforme demonstram Freeman (1995), Kliman e McGlone (1999), Kliman (2007), Carchedi (2011) e vários outros, a partir da ISUT da teoria do valor de Marx a soma dos preços é igual à soma dos valores, a magnitude do lucro é idêntica à magnitude da mais-valia e a taxa de lucro média em termos de valor é a mesma que a taxa de lucro média em termos de preço para cada período de produção considerado. Vale dizer, com base nessa interpretação, que todas as igualdades agregadas entre valores e preços apresentadas por Marx mostraram-se, assim, logicamente válidas.

A partir desta abordagem, Kliman (2012) analisa detidamente o movimento da taxa de lucro da economia norte-americana. Ao adotar uma perspectiva centrada no tempo histórico, como visto acima, o autor utiliza como dados para o estoque de capital os ativos fixos avaliados a custos históricos e não a custos correntes (ou de reposição) como em geral é utilizado pelos adeptos da interpretação convencional do valor de Marx. Assim, tomando sua medida de lucro mais abrangente ${ }^{19}$, denominada "renda da propriedade" (property income $\left.{ }^{20}\right)$, Kliman (2012, p. 77) observa que, de 1982 a 2001, período para o qual é comum se afirmar que a taxa de lucro se recuperou e iniciou uma trajetória sustentada de elevação, a rentabilidade reduziu-se $26,9 \%$. No entanto, se se avalia o estoque de capital a custos correntes, o movimento da taxa de lucro inverte-se. Observe que é aquela distinção teórica anteriormente mencionada que, ao se expressar na mensuração do estoque de capital, leva a conclusões absolutamente divergentes em relação à dinâmica da taxa de lucro nas últimas décadas.

\footnotetext{
19 Kliman (2012) afirma claramente que existem inúmeras formas de se medir o lucro - e, por conseguinte, a taxa de lucro - e que a escolha da mais adequada depende do propósito que se tem em mente. O próprio autor fornece várias dessas medidas em seu trabalho. No entanto, dados os propósitos do presente artigo e o fato de que os resultados obtidos por Kliman (2012) não se alteram em relação às diferentes medidas apresentadas, optou-se por expor aqui apenas aquela que mais parece se aproximar da taxa geral de lucro de Marx.

20 "What I call 'property income' is net value added minus compensation of employees" (Kliman, 2012, p. 99).
} 
Mas se é verdade que, tal como sustenta Kliman (2012), a taxa de lucro declinou ao longo das últimas décadas, como explicar este fenômeno?

Considere a descrição das variáveis apresentadas pelo autor no quadro abaixo.

\begin{tabular}{l|c|c}
\hline \multicolumn{1}{c}{ Variável } & Re-descrição heurística & \multicolumn{1}{c}{ Símbolo } \\
\hline Renda da propriedade & Mais-valia & $s$ \\
\hline Ativos fixos a custos históricos & Capital constante & $c$ \\
\hline Compensação dos empregados & Capital variável & $v$ \\
\hline $\begin{array}{l}\text { Razão da renda da propriedade } \\
\text { e a compensação dos empregados }\end{array}$ & Composição orgânica do capital & $\mathrm{s} / \mathrm{V}$ \\
\hline $\begin{array}{l}\text { Razão dos ativos fixos a custos históricos } \\
\text { e a compensação dos empregados }\end{array}$ & & \\
\hline
\end{tabular}

Fonte: Kliman (2012, p. 129; tradução nossa).

Se o capital variável, $v$, não for incluído no cálculo do estoque de capital, que se resume aos ativos fixos, $c$, tem-se que a taxa de lucro é dada por:

$$
\frac{S}{C}=\frac{S}{V} \cdot \frac{V}{C}
$$

Logo:

$$
\Delta \frac{S}{C} \approx \Delta \frac{S}{V}+\Delta \frac{V}{C}
$$

De acordo com o autor, uma vez que a taxa de mais-valia apresenta uma tendência praticamente constante no curso total de cada período considerado, é legítimo afirmar que sua influência sobre a trajetória da taxa de lucro é desprezível. Segundo suas estimativas, a taxa de lucro caiu 27,6\% entre 1947 e 2007, sendo que $89 \%$ desse declínio devem-se à elevação da composição orgânica do capital (ou ao declínio de seu inverso, como na fórmula acima), resultados que são consistentes com a lei de tendência à queda da taxa de lucro tal como Marx a apresenta (Kliman, 2012, pp. 130-131). Para Kliman, esses fatos dão suporte à ideia de que a queda da taxa de lucro constitui a causa última, subjacente, da Grande Recessão, chamada pelo autor de causa indireta:

Marx's theory holds precisely that a fall in the rate of profit leads to crises only indirectly and in a delayed manner. The fall leads first to increased speculation and the build-up of debt that cannot be repaid, and these are the immediate causes of crises. Thus, the timing of the current crisis and the sequence of events leading to it do not contradict the theory, but are fully consonant with it and lend support to it. Nothing anomalous has occurred that requires us to look elsewhere for explanations (Kliman, 2012, p. 22). 
O uso da ideia de "causa indireta" pelo autor é, aqui, bastante oportuno. Afinal, o declínio da taxa de lucro - e a queda da taxa de acumulação que dele resulta - não é causa direta, imediata, da crise. Os principais elos intermediários são o crédito (e a especulação a ele associada) e a própria baixa lucratividade, que diminui a capacidade de resistência do capitalista a mudanças no cenário econômico, tornando o sistema mais propenso a crises. Nesse sentido, há a sugestão de que, na tentativa de estimular a economia, o governo norte-americano e de outros países centrais vêm praticando, desde a crise da década de 1970, uma política monetária frouxa, favorecendo o endividamento, público e privado, e, assim, a especulação nos mercados financeiros. Isso evitou que o capital fosse desvalorizado num nível capaz de permitir a recuperação da taxa de lucro e acabou, portanto, por perpetuar o baixo crescimento econômico que se verificou nas últimas décadas. Desse modo, se, por um lado, tais medidas evitaram crises mais profundas, por outro, ao não permitirem que o capital se desvalorizasse, promoveram a formação de uma estrutura financeira frágil e insustentável. A Grande Recessão seria, assim, a expressão imediata, necessária, do acúmulo dessas fragilidades que, em última instância, derivariam do declínio prolongado da taxa de lucro.

\section{CONCLUSÃO}

Segundo Robert Skidelsky (2010), a Grande Recessão de 2007-09 suscitou, entre outros aspectos, o "retorno do mestre", em alusão ao fato de que os economistas, mesmo os ortodoxos, trouxeram as ideias de Keynes de volta ao centro do debate econômico.

O mesmo poderíamos dizer de outro "mestre", Karl Marx, tendo em vista a profusão de intervenções marxistas sobre a crise. De fato, uma pesquisa, por mais superficial que seja, dos vários livros que versam sobre a crise recente não deixará de se deparar com uma ampla gama de publicações de autores marxistas dos mais variados matizes.

Este artigo-resenha procurou revisar as principais análises de inspiração marxista sobre a Grande Recessão (2007-2009) a fim de caracterizar o debate em torno das suas causas. Desta caracterização resultou a possibilidade de identificar duas grandes abordagens quanto aos determinantes últimos da turbulência contemporânea.

De um lado encontraram-se aqueles que atribuem a Grande Recessão à dinâmica de uma fase particular do sistema capitalista - o capitalismo neoliberal - constituído ao longo das décadas de 1970-1980. Conforme se pôde observar, aqueles que defendem essa perspectiva enfatizam a estrutura institucional derivada das alterações da relação de poder entre as classes que compõem o capitalismo, apontando o seu reflexo sobre a economia e, particularmente, sobre o comportamento do setor financeiro e da distribuição de renda. De acordo com essa abordagem, a estrutura institucional forjada nas últimas décadas reflete o fortalecimento da classe capitalista. A estagnação dos salários reais, a elevação da taxa de lucro e a exa- 
cerbação da especulação nos mercados financeiros foram resultados desse novo arranjo, cuja dinâmica acabou por levar, em última instância, à crise.

Numa posição diversa, tem-se aqueles que atribuem a crise recente à dinâmica capitalista em geral, expressa nos movimentos das taxas de lucro e de acumulação. Para estes autores a taxa de lucro não se recuperou a partir da década de 1980 . Partindo daquilo que ficou conhecido como a Interpretação do Sistema Único Temporal, pretenderam demonstrar que o declínio da taxa de lucro, em virtude da elevação da composição orgânica do capital - tal como sustenta Marx (1985) -, constitui um princípio válido, e, sobretudo, consistente com a dinâmica da economia norte-americana nas últimas décadas. A queda da taxa de lucro, ao inibir o investimento e estimular as aplicações financeiras durante um período de tempo relativamente longo, criou as condições necessárias para que a economia apresentasse uma trajetória de endividamento insustentável, fenômeno que culminaria na Grande Recessão.

A implicação lógica dessa discordância teórica, ainda que relativamente pouco explorada, é bastante evidente. Conforme se observou, os primeiros, ao conceberem a Grande Recessão como resultante da dinâmica de uma etapa específica do capitalismo sugerem a possibilidade de que uma estrutura institucional diversa poderia evitar ou mitigar a crise. Vale dizer, que uma reforma adequada permitiria um capitalismo mais estável e, em certa medida, imune à crise. Os segundos, por sua vez, ao estabelecerem como causa última da Grande Recessão o que consideram ser uma tendência imanente ao sistema capitalista em geral - a tendência à queda da taxa de lucro -, são levados a argumentar pela inevitabilidade da crise. De acordo com essa perspectiva, apenas uma transformação profunda da sociedade, que significasse a substituição do capitalismo, seria capaz de evitar as turbulências dessa natureza. Embora distintas entre si, como se procurou aqui demonstrar - e em grande medida por causa disso -, essas obras indicam que a economia política marxista ainda se apresenta como um programa de pesquisa longe do esgotamento.

\section{REFERÊNCIAS BIBLIOGRÁFICAS}

Andrade, R. P. de e A. W. A. Palludeto (2013) "Harvey e o Enigma da Crise Econômica Recente". Revista de Economia Contemporânea, 17 (3): 570-576.

Baran, P. e P. Sweezy (1966) Monopoly Capital. New York: Monthly Review Press.

Berle, A. A. e G. C. Means (1932 [1968]) The Modern Corporation and Private Property. New York: Harcourt, Brace and World.

Bortkiewicz, L. von (1907 [1952]) "Value and Price in the Marxian System". International Economic Papers, 2: 5-60.

Carchedi, G. (2011) Behind the Crisis: Marx's Dialectics of Value and Knowledge. Leiden: Brill.

Choonara, J. (2009) "Marxist Accounts of the Current Crisis". International Socialism, 123: 1-22.

Cipolla, F. P. (2012) "Diferentes Teorias Marxistas de Crise e Diferentes Interpretações da Crise Atual”. Economia e Sociedade, 21(1): 39-59.

Clarke, S. (1994) Marx's Theory of Crisis. New York: St. Martin's Press.

Clarke, S. (2012) "Crisis Theory”. In: Fine, B. e A. Saad-Filho (2012) (eds.) The Elgar Companion to Marxist Economics. Cheltenham: Edward Elgar. 
Duménil, G. e D. Lévy (2011) The Crisis of Neoliberalism. Cambridge (MA): Harvard University Press. Filgueiras, L. (2010) A Crise Geral do Capitalismo: Possibilidades e Limites de sua Superação. Crítica Marxista, 30: 21-27.

Foster, J. B. (1986) The Theory of Monopoly Capitalism. New York: Monthly Review Press.

Foster, J. B. e F. Magdoff (2009) The Great Financial Crisis: Causes and Consequences. New York: Monthly Review Press.

Foster, J. B. e R. W. McChesney (2012) The Endless Crisis. New York: Monthly Review Press.

Freeman, A. (1995) “Marx without Equilibrium”. Capital \& Class, 19(2): 49-89.

Gontijo, C. e F. A. D. Oliveira (2009) Subprime: Os 100 Dias que Abalaram o Capital Financeiro Mundial e os Efeitos da Crise sobre o Brasil. Belo Horizonte: Corecon (MG).

Harvey, D. (2011) The Enigma of Capital and the Crises of Capitalism. $2^{\text {nd }}$ ed. London: Profile Books.

Kliman, A. (2007) Reclaiming Marx's "Capital": A Refutation of the Myth of Inconsistency. Lanham (MD): Lexington Books.

Kliman, A. (2010) The Persistent Fall in Profitability Underlying the Current Crisis: New Temporalist Evidence. New York: Marxist-Humanist Initiative.

Kliman, A. (2012) The Failure of Capitalist Production: Underlying Causes of the Great Recession. London: Pluto Press.

Kliman, A. e T. McGlone (1999) “A Temporal Single-System Interpretation of Marx's Value Theory”. Review of Political Economy, 11(1): 33-59.

Magdoff, H. e P. M. Sweezy (1987) Stagnation and Financial Explosion. New York: Monthly Review Press.

Mandel, E. (1975) Late Capitalism. London: Lowe e Brydone.

Marx, K. (1857-8 [1973]) Grundrisse - Foundations of the Critique of Political Economy (Rough Draft). London: Penguin Books.

Marx, K. (1885 [1992]) Capital, Vol. 2. London: Penguin Books.

Marx, K. (1894 [1991]) Capital, Vol. 3. London: Penguin Books.

Mattick, P. (1978) Anti-Bolshevik Communism. London: Merlin.

Okishio, N. (1961) “Technical Changes and the Rate of Profit". Kobe University Economic Review, 7: 85-99.

Palludeto, A. W. A. (2013) “As Possíveis Linhas Mestras do Debate Marxista sobre a Grande Recessão (2007-2009)". Anais do XLI Encontro Nacional de Economia, ANPEC.

Palludeto, A. W. A. e R. P. de Andrade (2014) "O Capital Monopolista-Financeiro e a Grande Recessão”. Estudos Econômicos, 44 (4): 881-888.

Prado, E. F. S. (2013) "Duas Explicações Marxistas para a Grande Falha do Capitalismo”. In: Barroso, A. S. e R. Souza. A Grande Crise Capitalista Global 2007-2013: Gênese, Conexões e Tendências. São Paulo: Anita Garibaldi; Fundação Maurício Gabrois.

Saad-Filho, A. (2002) The Value of Marx: Political Economy for Contemporary Capitalism. London: Routledge.

Shaikh, A. (1978) "An Introduction to the History of Crisis Theories". In: Union for Radical Political Economics (URPE). U.S. Capitalism in Crisis. New York: Monthly Review Press.

Shaikh, A.. (1991) “Economic Crises”. In: Bottomore, T. (1991) (ed.) A Dictionary of Marxist Thought. Oxford: Blackwell.

Skidelsky, R. (2010) Keynes: The Return of the Master. New York: Public Affairs.

Sraffa, P. (1960) Production of Commodities by Means of Commodities: Prelude to a Critique of Economic Theory. Cambridge (UK): Cambridge University Press.

Steedman, I. (1977) Marx After Sraffa. London: New Left Books.

Sweezy, P. M. (1942) The Theory of Capitalist Development. New York: Monthly Review Press. 